Society for the Anthropology of Work • Policing and Labor

\title{
Whose University? When Police Pass the Baton to Campuses
}

\section{Lachlan Summers, Kathryn Gougelet}

Published on: Dec 01, 2020

DOI: $10.21428 / 1 \mathrm{~d} 6 \mathrm{be} 30 \mathrm{e} .8 \mathrm{cc} 96 \mathrm{f} 6 \mathrm{f}$

License: Creative Commons Attribution 4.0 International License (CC-BY 4.0). 
In the summer of 2020, as Black Lives Matter demonstrations rallied against state-sanctioned antiBlack police violence across the United States, police abolition entered the political mainstream and calls to get cops off university campuses gained momentum. University of California (UC) Board of Regents Chair John A. Pérez and UC President Janet Napolitano issued a joint statement on policing, claiming that "the University of California will take immediate action to re-examine our own practices" around policing. A few weeks later, the UC's Academic Senate demanded the "substantial defunding" of UC campus police and the reinvestment of these resources in alternative modes of campus safety.

While these developments might suggest that the UC system is ready to hold itself accountable for its relations with institutions of state violence, they have not in fact changed the extent of police presence. Indeed, many UC campuses are increasing their policing budgets for the 2020-21 academic year, despite delivering most classes online. Moreover, the University of California, Santa Cruz (UCSC) wildcat strike of 2019-2020 demonstrates campus administrators' willingness to assume the role of police as a means of managing campus activism. We argue that this blurry line between campus and police is an intentionally ambiguous boundary that the university maintains in order to uphold and enforce the stark division between academic security and precarity.

Facing some of the highest rents in the country and pay that had long fell out of pace with the cost of living, graduate student workers at UCSC_-including the authors-initiated a wildcat strike in December 2019 to demand a Cost of Living Adjustment (COLA) that would alleviate our rent burden. UCSC's own research puts the average one-bedroom apartment at \$2,013 per month, while graduate students make $\$ 2,100$. A grading strike, in which graduate student workers withheld from administration the grades of the undergraduates we had been teaching, escalated to a full teaching strike and picket on February 10, 2020. 


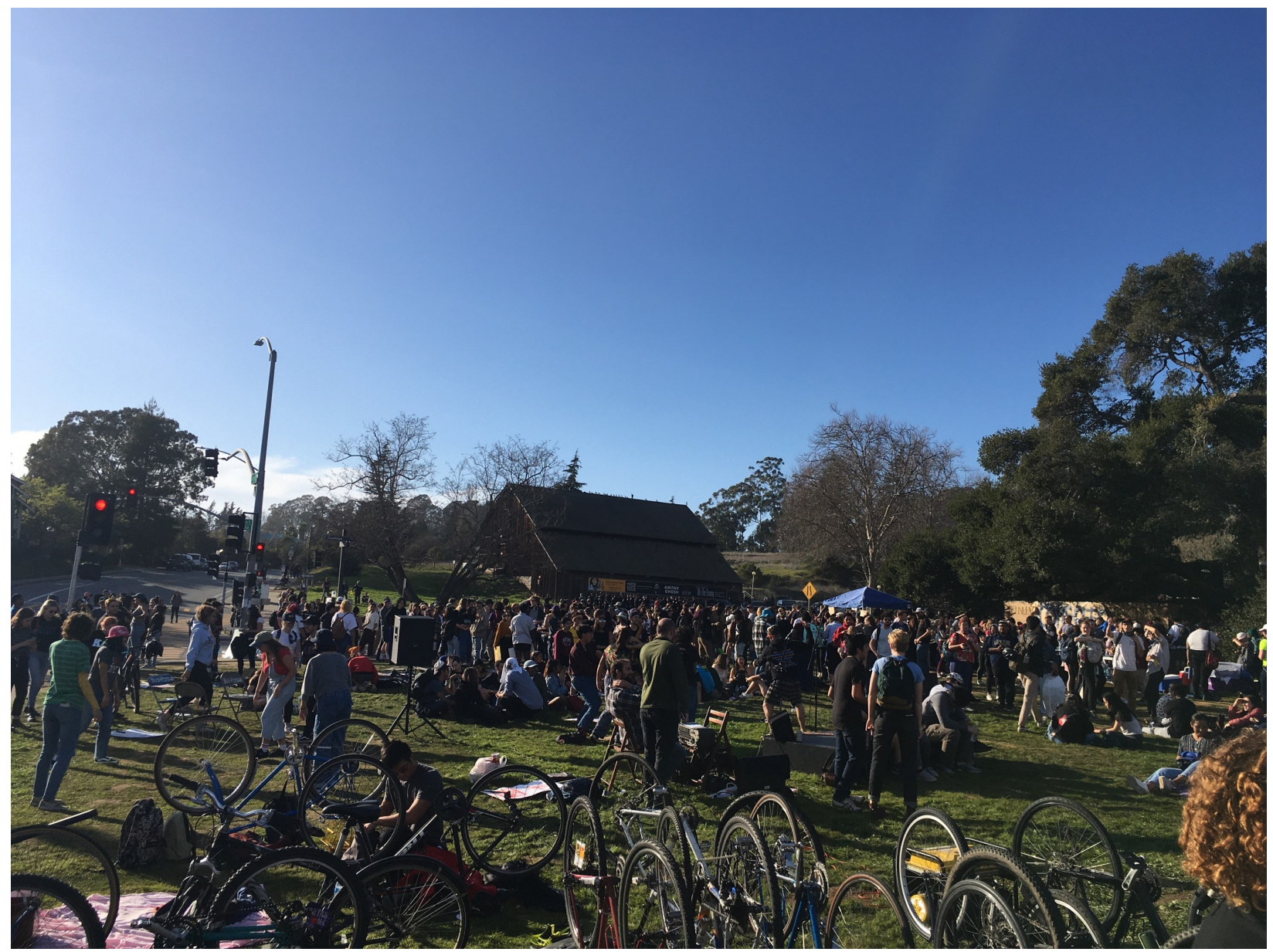

Picket of about three hundred people at the base of campus on February 12. In the foreground is the bike repair space, in the middle a dance floor. Photo by Lachlan Summers.

The picket was intended to be peaceful: a site where graduate students and their undergraduate, faculty, and staff allies could build community, generate solidarities, host speak-outs, and draw attention to the untenable living conditions that UCSC had long acknowledged but never addressed. Refusing dialogue with strikers, Chancellor Cynthia Larive and Executive Vice Chancellor Lori Kletzer met the picket with a massive police force. At least eighty armed police officers were present at the picket, with dozens more waiting in surrounding car parks. These officers came from UCSC's own police force, from other UC campuses, from the Santa Cruz Police Department, and from noncampus police departments across the Bay Area. Later reporting established that UCSC's police had enlisted military surveillance from California's National Guard to monitor picket activities. During a meeting with the copresidents of the Graduate Student Assembly, Kletzer estimated that this display of force cost $\$ 300,000$ per day, which would set the total price of policing the picket at around $\$ 5$ million. 


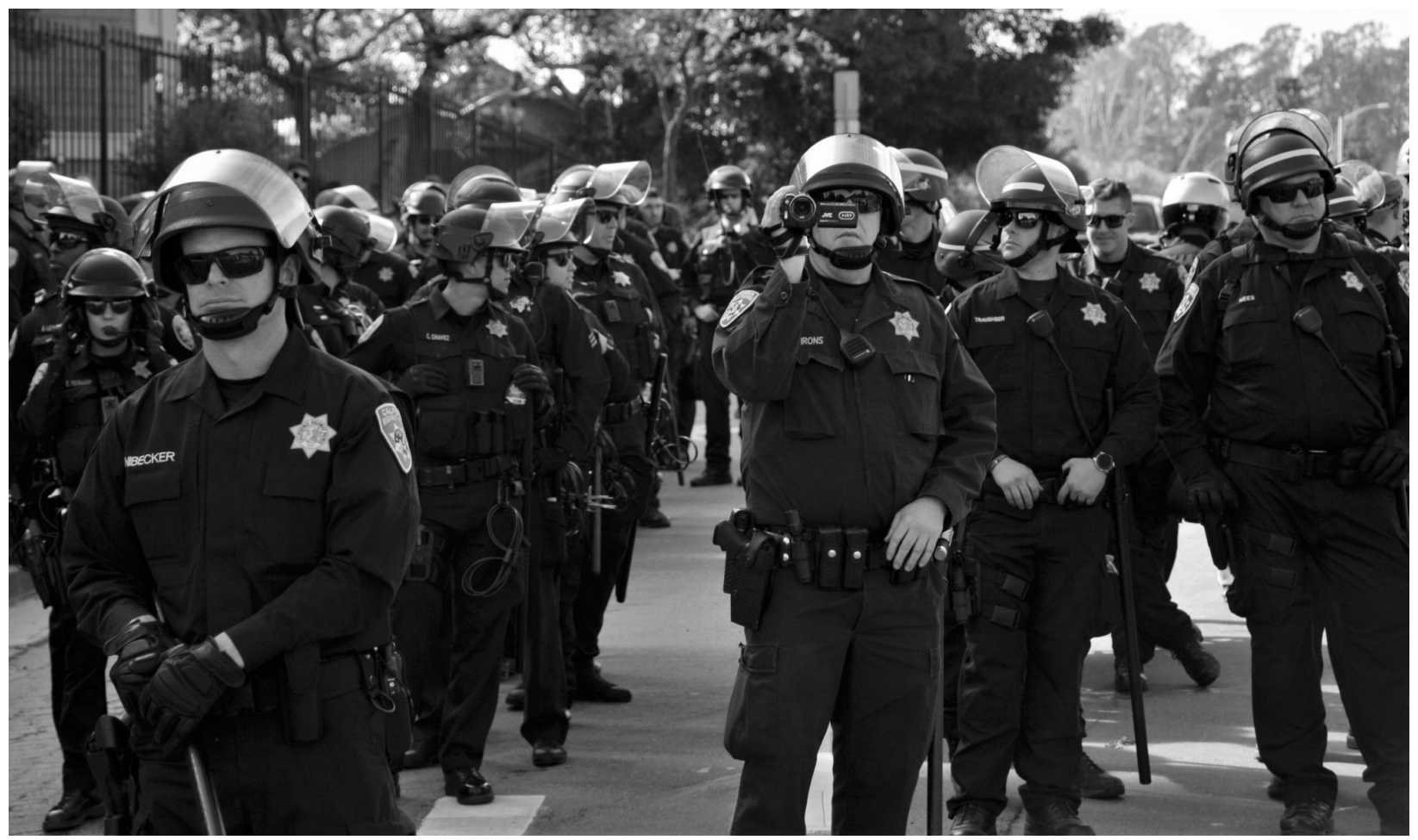

Dozens of riot police standing in formation on day three of the picket. Photo courtesy of Ali Fuat Yuvall.

On the first day of the picket, a student was arrested for delivering water; another was cited for crossing a crosswalk too slowly; still another suffered a concussion after being hit with police batons. On the third day, during an hours-long standoff between riot police and students, seventeen people were arrested, while numerous others were beaten and subject to pain compliance techniques. Away from the picket, students were arrested and cited for apparently unrelated infractions, while others reported being followed as they drove home from the picket or having police stationed outside their houses. The police response was widely condemned on social media, in the press, and by the UC's own Academic Senate. Perhaps recalling the public relations disaster when police officers casually peppersprayed students at the University of California, Davis in 2011, including the ensuing legal costs and the money the university paid image consultants to scrub troubling images from the Internet, UCSC advised the police to deescalate.

\section{The Original Authority on Questioning Authority?}

By late February, police made themselves scarce. Shortly thereafter, UCSC began to implement a more discreet and pernicious form of policing. First, eighty-two graduate student workers, including one of us (Lachlan), were fired from their spring teaching positions. Next, administrators formed a Demonstrations Operations Team (DOT), an opaque entity. about which little has been made public. While the firing of strikers was an expected retribution for the labor strike, what was unexpected is how DOT moved to implement parallel charges against strikers under the broad umbrella of student 
conduct. In conduct proceedings, administrators threatened students with academic probation and expulsion for actions they took as workers.

In compiling evidence of student misconduct, university officials actively collaborated with the police forces that had monitored the picket. Administrators relied on police evidence for many student conduct hearings; these reports were often racialized, disproportionately charging Black, Indigenous, and people of color (BIPOC) students with acting "aggressive" and "intimidating." One summons stated that a student "stared at [an administrator] in an attempt to intimidate her," an effort to police students' body language that was widely seen as seeking to enforce a version of respectability politics (see Cox 2015). Police recordings obtained through a public records request also showed that one firstgeneration Latinx student, Carlos Cruz, was actively singled out by police at the picket. In the student conduct process, UCSC administrators charged Cruz with resisting arrest, utilizing police statements as evidence, even though the police themselves did not pursue charges. The outcome of his student conduct process was a two-year suspension that he and his allies are actively contesting. This unhesitating use of subjective and racialized police reports demonstrates a startling continuity between policing and the university.

Internalizing police functions enabled administrators to escalate charges beyond what could be accomplished by the police alone. The campus IT department collaborated with administrators to surveil graduate student worker use of the Canvas course management system. It provided administrators with data on Canvas users who had "modified" grades on the online system - this included both graduate students who deleted grades and those who were carrying out their normal teaching duties-during the grading strike. Canvas-related charges were brought against at least seventy-five students, and some Canvas users who were not actively participating in the strike were summoned for conduct hearings simply for updating large numbers of grades as the quarter closed. Student conduct letters accused those who had modified grades in Canvas of everything from "theft" of the university's intellectual property to "forgery." Though couched in legal language, no formal legal proceedings took place: the UCSC administration used their extralegal powers to punish students beyond what might have been possible through formal legal mechanisms.

Internalizing policing permitted UCSC to escalate charges against students because labor law and free expression rights had been supplanted by an extralegal framework. "Forgery" of grades during the strike is unlikely to have held up in court, as teaching assistants were not legally required to use the Canvas system. Indeed, they were never even formally trained in how to use Canvas, making charges of "improper use" questionable at best. Instead, management of campus activism was governed by the UC's Enterprise Risk Management (ERM)_plan. Adopted in 2003, the ERM foregrounds "continuity of operations" as the university's central concern, and transforms risks into Key Performance Indicators that evaluate how effectively UC campuses maintain continuity. A 2016-2017 report from the UC Office 
of the President identified twenty-five incidents that had required ERM planning; amid the power outages, fires, and storms, nine of these incidents were campus protests. This managerial, revenuefocused approach to risk renders protests commensurate with fires, bombs, tsunamis, shootings, hazardous materials, and earthquakes. Here, "risk" and "continuity" became the foundational edicts of campus management, and the administrators charged with eliminating risk in the name of continuity were the same ones who oversaw UCSC's conduct charges against strikers and their allies.

\section{Cops Off Campus, COLA in Our Bank Accounts}

This translation of questions of legality into risks to continuity was veiled by empty managerial phrases like "educational mission," which were regularly deployed by administrators communicating with graduate student workers throughout the strike. While these corporate oxymorons (see Benson and Kirsch 2010) serve to mask the ultimately revenue-focused conduct charges, they also betray a specific imagination of the university. Higher education currently relies on an ever-increasing number of debt-saddled undergraduates, a rapidly expanding precariat that teaches them, and the tenurestream faculty who undertake the reputation-building research that increases undergraduate enrollments. Tenured faculty, feeling the pressure of this acceleration, have responded with calls for slow scholarship (Mountz et al. 2018), but this slow scholarship requires what Eli Meyerhoff (2019: 18) calls an "unequal temporal architecture," in which tenured faculty's opportunities to research and publish increasingly depends on the sped-up labor of service workers, contingent faculty, and graduate student workers.

Notably, our strike was visibly supported by unions of precarious workers, like AFSCME 3299 and UCAFT, but faculty support mostly came from assistant professors. While some tenured faculty were more explicitly supportive, support at this level largely consisted only of writing statements and letters on our behalf, a form of action that defended strikers, but did so by relying on the idea that tenured academics are public intellectuals, perhaps troubled by the university's punitive actions but above the fray of labor struggles. While tenured faculty articulated their personal commitment to us as individuals, they were reticent to support us as a collective, ultimately entrenching the divide between intellectuals aligned with an "educational mission" and workers merely asking for money.

For the four weeks of the picket, chants echoed almost continuously around the base of the UCSC campus. "My neck, my back, the UC is whack!" was a crowd favorite, as was "Whose university? Our university!" A critical chant from the earliest stages of the movement was "Cops off campus, COLA in our bank accounts." Driven by the experience and organizing work of BIPOC strikers, we recognized that this referred not just to police officers, but to the logic of policing that could carry through the campus (see Shange 2019). UCSC internalized policing to defend the university-as-usual, firing rentburdened students already at risk of houselessness, banning first-generation BIPOC students from campus, denying undocumented students access to on-campus resources, and threatening 
international students with deportation. Moreover, by weaponizing the campus's "educational mission," UCSC defended the faculty's right to slow scholarship by policing the workers who undertake much of the labor of educating.

Abolishing police from campus thus requires recognizing how internalized mechanisms of policing enable the slow scholarship of tenured faculty. Slow scholarship could help to make a world without police. But what is first required is a collective undoing-across all levels of the university labor forceof the conditions that currently make such scholarship possible. For several weeks, the picket at the base of the UCSC campus gave a glimpse of what such an undoing could look like.

\section{Author Bios}

Lachlan Summers is a $\mathrm{PhD}$ candidate in the Department of Anthropology at the University of California, Santa Cruz, where he researches earthquake politics in Mexico City. He and his friends were finally reinstated on August 11, 2020, while writing this piece, after having been fired during the wildcat strike of 2019-2020. He is a Contributing Editor at the Society for Cultural Anthropology, a member of the Emergent Futures CoLab, and is on Twitter at @backup sandwich.

Kathryn Gougelet is a nonfiction writer and a $\mathrm{PhD}$ student in the Department of Anthropology at the University of California, Santa Cruz, where she studies the relationships between environmental toxicants and COVID-19 outcomes in Catalunya's Francolí River Valley. Her recent writing has appeared in The Normal School, Terrain.org, and Essay Daily. Follow her on Twitter at @kgougelet.

\section{Resources for Action}

While we were writing this essay, a coalition of faculty, students, and activists came together with the central demand of removing police from University of California and California State University campuses by 2021 .

Strike University.

$\underline{\text { FUC }}$

PayUsMoreUCSC

\section{Preview Image}

Photo by Chris Henry.

\section{References}

Benson, Peter, and Stuart Kirsch. 2010. “Corporate Oxymorons." Dialectical Anthropology 34: 45-48. 
Cox, Aimee Meredith. 2015. Shapeshifters: Black Girls and the Choreography of Citizenship. Durham, NC: Duke University Press.

Meyerhoff, Eli. 2019. Beyond Education: Radical Studying for Another World. Minneapolis: University of Minnesota Press.

Mountz, Alison, et al. 2018. "For Slow Scholarship: A Feminist Politics of Resistance through Collective Action in the Neoliberal University." ACME 14(4): 1235-59.

Shange, Savannah. 2019. Progressive Dystopia: Abolition, Anti-Blackness, and Schooling in San Francisco. Durham, NC: Duke University Press. 